\title{
NMDA Receptor Channels: Labeling of MK-801 with Iodine-125 and Fluorine-18
}

\author{
D. M. WIELAND,* M. R. KILBOURN, D. J. YANG, E. LABORDE, \\ D. L. GILDERSLEEVE, M. E. VAN DORT, J-L. PIRAT, \\ B. J. CILIAX' ${ }^{1}$ and A. B. YOUNG ${ }^{\prime}$
}

Division of Nuclear Medicine, Department of Internal Medicine and ${ }^{1}$ Department of Neurology, University of Michigan Medical School, Ann Arbor, MI 48109, U.S.A.

(Received 19 April 1988)

\begin{abstract}
Methods for labeling the glutamate channel blocking agent MK-80I with iodine-125 ( $\left.{ }^{125} \mathrm{I}\right)$ and fluorine- 18 $\left({ }^{18} \mathrm{~F}\right)$ are described. Radioiodine was incorporated in the 1- or 3-positions of the aromatic ring of $( \pm) \mathrm{MK}-801$ by solid-state halogen exchange techniques. Attachment of the $\left[{ }^{18} \mathrm{~F}\right]$ fluoromethyl group to the bridgehead methyl position was achieved by reaction of $\left[{ }^{18} \mathrm{~F}\right]$ fluoride with the triflamide alcohol 8 or the novel cyclic sulfamate 9 recently reported by Merck chemists. Radiochemical yields of $( \pm) 13-\left[{ }^{18} \mathrm{~F}\right]-$ fluoromethyl-MK-801 were $>72 \%$, EOB; radiochemical purity $>99 \%$. In competitive binding studies using rat brain homogenates, $( \pm)$-bromo-MK-801 showed greater affinity than $( \pm)$ MK-801 for the glutamate-linked channel. The experimental $\log P(2.1 \pm 0.1)$ of MK-801 is optimal for transit of the blood-brain barrier. These preliminary findings support further testing of $3-\left[{ }^{123} \mathrm{I}\right]$ iodo-MK-801 and ( \pm ) $13-\left[{ }^{18} \mathrm{~F}\right]$ huoromethyl-MK-801 as possible agents for in vivo mapping of the glutamate receptor complex.
\end{abstract}

\section{Introduction}

The amino acid glutamate is a major excitatory neurotransmitter in mammalian brain (Watkins and Evans, 1981). MK-801, a potent anticonvulsant and neuroprotective agent, has been shown to noncompetitively bind to a subset of glutamate binding sites termed the N-methyl-D-aspartate (NMDA) receptor (Wong et al., 1986, 1988). Activation of the

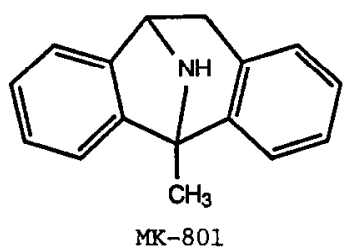

NMDA receptor opens a channel that permits $\mathrm{Ca}^{2+}$ and other cations to pass into the neuron. It is to this channel, when in the open state, that MK-801 is thought to bind. The psychotropic drug phencyclidine (PCP) has also been shown to bind to this NMDA-operated open channel (Honey et al., 1985). However, MK-801 binds with greater affinity and

"Correspondence should be addressed to: Donald $M$. Wieland, Ph.D., University of Michigan, Cyclotron PET Facility, 3480 Kresge III Building, Ann Arbor, MI 48109-0522, U.S.A. specificity; it has a $K_{\mathrm{D}}$ of $6.3 \mathrm{nM}$ for the NMDA receptor channel and little affinity for the sigma opiate receptor (Wong et al., 1988).

The NMDA receptor complex may play a pivotal role in many brain diseases. Excessive stimulation of NMDA receptors has been implicated in neurodegenerative disorders such as Alzheimer's disease (Greenamyre et al., 1985; Deutsch and Morisha, 1988), psychotic processes (Olney, 1987), epilepsy (Meldrum, 1987) and ischemia-induced neuronal degeneration. Initial studies in animal models of both global and focal ischemia have shown that MK-801 protects against glutamate-induced neuronal damage when given before or shortly after the ischemic insult (Kemp et al., 1987).

The goal of this preliminary work was to explore strategies for synthesizing radiolabeled derivatives of MK-801 for in vivo mapping of the NMDAlinked cation channel. Both radioiodinated and ${ }^{11} \mathrm{C} /{ }^{18} \mathrm{~F}$-tracers have been pursued in hopes of developing agents for evaluation by SPECT and PET, respectively. Synthetic routes to $\mathrm{MK}-801$ and its analogs are described only in the patent literature; structure-activity relationship (SAR) studies have not been published. This report describes the synthesis of two isomeric ${ }^{125}$ I-labeled derivatives of ( \pm MK-801 and a $\left[{ }^{18}\right.$ F]fluoromethyl derivative. Results of $K_{\mathrm{i}}$ value determinations for these three derivatives suggest that two of the tracers merit in vivo evaluation as NMDA receptor channel markers. 


\section{Experimental}

\section{Materials and methods}

$( \pm) M K-801 \quad[( \pm)-5$-methyl-10,11-dihydro-5H-dibenzo[a,d]cyclohepten-5,10-imine] and its 13-hydroxymethyl derivative 1 were synthesized according to patent procedures (Anderson et al., 1983; Bender et $a l ., 1984)$. The cyclic sulfamate 9 and its sulfonamide precursor 8 were obtained by a slight modification of the method of Lyle et al., 1987. Racemic 3-bromoMK-801 was a generous gift of Merck Sharp \& Dohme Research Laboratories, West Point, Penn. $\mathrm{Na}\left[{ }^{125} \mathrm{I}\right]$ (no carrier added) and $\left[{ }^{3} \mathrm{H}\right] \mathrm{TCP}$ were purchased from Dupont/NEN.

Thin-layer chromatography (TLC) was performed on Whatman $\mathrm{K} 6 \mathrm{~F}$ silica gel glass-backed plates $(250 \mu \mathrm{m})$, E. Merck neutral alumina plastic-backed plates $(0.2 \mu \mathrm{m})$, or Whatman $\mathrm{KC} 18 \mathrm{~F}$ reverse phase glass-backed plates $(200 \mu \mathrm{m})$. Sep-Paks ${ }^{\mathrm{TM}}$ were from Waters Associates. Flash chromatography was performed by the procedure of Still et al. (1978). Highpressure liquid chromatography (HPLC) was carried out on either a Waters system consisting of a Model 680 gradient controller, two Model 510 pumps, and Model U6K injector, or on a combined system composed of a Beckman Model 110B pump and a Rheodyne Model 7125 injection valve fitted with a $500 \mu \mathrm{L}$ sample loop. Detection was performed with either a Kratos Model SF773 u.v./vis. detector at $230 \mathrm{~nm}$ or an ISCO Model UA-5 u.v. detector with a $280 \mathrm{~nm}$ filter, and a Beckman Model 170 or a Radiomatic Model DR/IC Flo-One radioisotope detector.

Melting points were determined on a Fisher-Johns melting point apparatus and are uncorrected. RadioTLC chromatograms were scanned on a Berthold Linear Analyzer LB 282. Infrared spectra were recorded on either a Perkin-Elmer 727B or a Nicolet $5 \mathrm{X}$ FT-i.r. spectrometer. ${ }^{1} \mathrm{H}-\mathrm{NMR}$ spectra were obtained on a Varian EM-360 (60 MHz), a Bruker AM-300 (300 MHz) or a Bruker WM-360 (360 MHz) instrument. ${ }^{13} \mathrm{C}$-NMR spectra were recorded on a Bruker WM-360 instrument at $90.5 \mathrm{MHz}$ and are completely decoupled. Mass spectra were obtained on a Finnigan 4021 GCMS/DS (low resolution) or a VG70-250-S (high resolution) instrument. GC/MS analyses were done on a Hewlett-Packard 5890 gas chromatograph equipped with a mass selective detector with a direct interface. Elemental analyses were performed by Spang Microanalytical Laboratories, Eagle Harbor, Mich.

\section{In vitro binding assay}

The affinity of the compounds for the NMDAlinked receptor channel was determined using the procedure of Vignon et al., $(1983,1986)$ with modifications. Male Sprague-Dawley rats $(250 \mathrm{~g})$ were killed by decapitation. The cerebral cortices were dissected and homogenized for $15 \mathrm{~s}$ in $50 \mathrm{~mL}$ of Tris acetate buffer $(50 \mathrm{mM}, \mathrm{pH} 7.2$ at $4 \mathrm{C})$ using a Brinkmann tissue homogenizer. The crude mem- brane receptor preparation was kept in an ice-cold bath until measurement of $\left[{ }^{3} \mathrm{H}\right] \mathrm{TCP}$ binding. This measurement was performed by incubating $1 \mathrm{~mL}$ (triplicate aliquots) of the crude membrane suspension ( $c a 45 \mathrm{mg}$ of protein) with $20 \mu \mathrm{L}$ of either a solution of the test compound in methanol or the buffer alone (total binding), and $1 \mathrm{~mL}$ of $6 \mathrm{nM}$ [ $\left.{ }^{3} \mathrm{H}\right] \mathrm{TCP}$. Unlabeled TCP, $20 \mu \mathrm{L} \quad(20 \mu \mathrm{M}$ final concentration) was used for determination of nonspecific binding.

The binding reaction was initiated by adding $\left[{ }^{3} \mathrm{H}\right] \mathrm{TCP}$ to the membrane suspensions and allowing the tubes to stand at room temperature for $1 \mathrm{~h}$. Incubation was terminated by rapid filtration through Whatman GF/B filters presoaked with $0.5 \%$ aqueous polyethylenimine. The filters were rapidly washed 3 times with $5 \mathrm{~mL}$ cold buffer and then suspended in $5 \mathrm{~mL}$ of Hydrofluor and allowed to stand at room temperature for $1.5 \mathrm{~h}$ before liquid scintillation counting. Protein concentrations were determined according to the method of Bradford (1976).

We previously reported saturation curves for $\left[{ }^{3} \mathrm{H}\right] \mathrm{TCP}$ binding to rat brain homogenates (Albin $e t$ al., 1988). Scatchard analysis indicated a single class of binding sites with a mean $K_{\mathrm{d}}$ of $45 \mathrm{nM}$ and a mean $B_{\max }$ of $773 \mathrm{fmol} / \mathrm{mg}$ protein. In this study, the concentrations of unlabeled MK-801 derivatives displacing $50 \%$ of specific $\left[{ }^{3} \mathrm{H}\right] \mathrm{TCP}$ binding $\left(\mathrm{IC}_{50}\right)$ were determined. The binding affinity constants $\left(K_{i}\right)$ were then calculated using the equation: $K_{\mathrm{i}}=\mathrm{IC}_{50} /\left(1+[L] / K_{\mathrm{d}}\right)$; the concentration of $\left.{ }^{3} \mathrm{H}\right] \mathrm{TCP}$ ([L]) utilized in the inhibition studies was $6 \mathrm{nM}$.

\section{Log $P$ determination}

The $\log P$ of MK-801 was determined according to the method of Frey et al. (1983), using unlabeled compound (free base) and octanol/phosphate buffered saline (PBS), pH 7.4. The amount of MK801 in the PBS phase was determined spectrophotometrically by extraction with ethyl ether, solvent removal, redissolving in absolute ethanol and comparison with a standard curve of free base MK-801 obtained in ethanol at $276.5 \mathrm{~nm}$. Three determinations were made.

\section{Preparation of $( \pm) 1$-iodo- $M K-801$}

To a solution of $( \pm) \mathrm{MK}-801(315 \mathrm{mg}, 1.40 \mathrm{mmol})$ in $85 \% \mathrm{H}_{2} \mathrm{SO}_{4}(17 \mathrm{~mL})$ were added silver sulfate (222 $\mathrm{mg}, 0.21 \mathrm{mmol})$ and iodine $(181 \mathrm{mg}, 0.71 \mathrm{mmol})$. The resulting mixture was stirred at room temperature for $7 \mathrm{~h}$. It was then cooled to $0^{\circ} \mathrm{C}$ and carefully neutralized with $10 \% \mathrm{NaOH}$. The neutral solution was extracted with $\mathrm{CH}_{2} \mathrm{Cl}_{2}(3 \times 10 \mathrm{~mL})$ and the combined extracts were dried over $\mathrm{MgSO}_{4}$ and concentrated in vacuo. GC/MS analysis of this crude material showed one major $\left(t_{\mathrm{R}}=9.59 \mathrm{~min}, \mathrm{c} a 79 \%\right.$ chemical yield) and two minor monoiodinated products. Flash chromatography using hexane:ethyl acetate $1: 1$ provided a heart fraction $(25 \mathrm{mg})$ of 
the major isomer as a clear oil; ' $\mathrm{H}-\mathrm{NMR}\left(\mathrm{CDCl}_{3}\right)$ : $\delta=1.92\left(\mathrm{~s}, 3 \mathrm{H}, \mathrm{CH}_{3}\right) ; 2.46-2.56(\mathrm{~m}, 1 \mathrm{H}, \mathrm{NH}) ; 2.59$ (d, $1 \mathrm{H}, \mathrm{J}=17.2 \mathrm{~Hz}, \mathrm{H}_{11 \alpha}$ ); 3.23 (dd, $1 \mathrm{H}, \mathrm{J}=17.2$, $\left.5.7 \mathrm{~Hz}, \mathrm{H}_{11 \beta}\right) ; 4.73\left(\mathrm{~d}, 1 \mathrm{H}, \mathrm{J}=5.7 \mathrm{~Hz}, \mathrm{H}_{10}\right) ; 7.62(\mathrm{dd}$, $\left.1 \mathrm{H}, \mathrm{J}=7.9,1.1 \mathrm{~Hz}, \mathrm{H}_{2}\right) ; 6.82\left(\mathrm{t}, 1 \mathrm{H}, \mathrm{J}=7.8 \mathrm{~Hz}, \mathrm{H}_{3}\right)$; $7.05-7.07\left(\mathrm{~m}, \mathrm{H}_{6}\right) ; 7.12\left(\mathrm{td}, 1 \mathrm{H}, \mathrm{J}=7.3,1.5 \mathrm{~Hz}, \mathrm{H}_{7}\right)$; $7.15\left(\mathrm{td}, 1 \mathrm{H}, \mathrm{J}=7.3,1.6 \mathrm{~Hz}, \mathrm{H}_{8}\right) ; 7.27-7.33(\mathrm{~m}, 2 \mathrm{H}$, $\mathrm{H}_{4}$ and $\left.\mathrm{H}_{9}\right) ;{ }^{13} \mathrm{C}-\mathrm{NMR}\left(\mathrm{CDCl}_{3}\right): \delta=20.08,\left(\mathrm{CH}_{3}\right)$; $41.67\left(\mathrm{C}_{11}\right) ; 58.63\left(\mathrm{C}_{10}\right) ; 64.19\left(\mathrm{C}_{5}\right) ; 103.83\left(\mathrm{C}_{1}\right)$; $118.64,121.53,126.95,127.05,127.57,137.88,135.21$, $144.49,146.60,151.27$; mass spectrum, $m / e 347\left(\mathrm{M}^{+}\right)$.

Treatment of this oil with $\mathrm{HCl}$ provided the corresponding hydrochloride salt; m.p. $205-207^{\circ} \mathrm{C}$. Anal. Calc. for $\mathrm{C}_{16} \mathrm{H}_{14} \mathrm{IN} \cdot \mathrm{HCl}$ : C, 50.09; H, 3.94; N, 3.65 . Found: C, 49.69; H, 3.69; N, 3.46.

\section{Synthesis of $( \pm) I-I^{125}$ IJiodo-MK-80I}

Radioiodide labeling was achieved by an ammonium sulfate catalysed solid-phase exchange technique described previously (Mangner et al., 1982; Otto et al., 1986). Exchanges were conducted in $3 \mathrm{~mL}$ septum sealed multi-dose vials vented with a disposable $10 \mathrm{~cm}^{3}$ plastic syringe which served as the distillate condenser. Charcoal and aqueous sodium thiosulfate traps were connected in series with the condenser to trap any volatile radioiodine that was released during the heating process. In a typical procedure, a solution containing $6.3 \mathrm{mg}$ of $\left(\mathrm{NH}_{4}\right)_{2} \mathrm{SO}_{4}, 25 \mu \mathrm{g}$ of $( \pm) 1$-iodo-MK-801, and $6.5 \mathrm{mCi}$ of $\mathrm{Na}^{125} \mathrm{I}$ in $300 \mu \mathrm{L}$ of ethanol/water $(1: 1)$ was heated to dryness in an oil bath at $180^{\circ} \mathrm{C}$. Air $(10 \mathrm{~mL})$ was slowly injected over a $1-\mathrm{min}$ period, and the reaction mixture was maintained at $180-185^{\circ} \mathrm{C}$ for an additional $30 \mathrm{~min}$. After cooling to room temperature, the reaction mixture was extracted with acetone $(500 \mu \mathrm{L})$ and analyzed by radio-TLC (silica: $\mathrm{Et}_{2} \mathrm{O}: \mathrm{CH}_{3} \mathrm{CN}: \mathrm{NH}_{4} \mathrm{OH}, \quad 70: 30: 5 ; R_{\mathrm{f}}=0.28$; radiochemical yield $83 \%$ ). Evaporation of the acetone left a residue which was extracted with $\mathrm{CH}_{2} \mathrm{Cl}_{2}$ $(2 \times 1.0 \mathrm{~mL})$ and transferred to a silica Sep-Pak. The Sep-Pak was successively washed with $4 \mathrm{~mL}$ each of hexane, hexane/EtOAc $(9: 1)$, hexane/EtOAc $(3: 1)$, and hexane/EtOAc $(1: 1)$ to remove less polar impurities. Subsequent elution with $4 \mathrm{~mL}$ of EtOAc yielded $2.8 \mathrm{mCi}$ of desired product; radiochemical purity was $>99 \%$ by radio-TLC and isolated radiochemical yield was $47 \%$. The specific activity was $>60 \mathrm{Ci} / \mathrm{mmol}$.

The radioligand was stored in absolute ethanol $(5.8 \mathrm{mCi} / \mathrm{mL})$ at $-20^{\circ} \mathrm{C}$ in the dark until needed. Under these conditions, no radiolytic decomposition was ohserved up to 46 days after synthesis. Just prior to biological testing the solvent was evaporated and the compound was formulated in ethanol $/ 5 \mathrm{mM}$ sodium acetate buffer, pH 4.5, (15:85).

\section{Synthesis of $( \pm) 3-I^{125}$ Ifiodo-MK-80I}

In a typical procedure, a solution of $\left(\mathrm{NH}_{4}\right)_{2} \mathrm{SO}_{4}$ ( $5.0 \mathrm{mg}$ in $15 \mu \mathrm{L}$ of deionized $\mathrm{H}_{2} \mathrm{O}$ ), ( \pm )3-bromo$\mathrm{MK}-801 \cdot \mathrm{HCl}(100 \mu \mathrm{g}$ in $100 \mu \mathrm{L}$ of cthanol) and
$7.27 \mathrm{mCi}$ of $\mathrm{Na}^{125} \mathrm{I}$ were combined and heated to dryness at $230^{\circ} \mathrm{C}$ in an oil bath. Air was then slowly passed through the reaction vial for $1 \mathrm{~min}$. The dry mixture was maintained at $230^{\circ} \mathrm{C}$ for an additional $30 \mathrm{~min}$, cooled to room temperature, dissolved in acetone $(200 \mu \mathrm{L})$ and subjected to radio-TLC analysis (silica, $\mathrm{CH}_{3} \mathrm{CN}: \mathrm{Et}_{2} \mathrm{O}: \mathrm{NH}_{4} \mathrm{OH}, 3: 7: 0.1$ ). Following removal of the acetone by means of a gentle stream of argon, the dry reaction mixture was dissolved in $\mathrm{CH}_{2} \mathrm{Cl}_{2}(3 \times 0.5 \mathrm{~mL})$ and transferred to a silica Sep-Pak ${ }^{\mathrm{TM}}$. Elution with hexanes $(10 \mathrm{~mL})$ followed by EtOAc $(5 \mathrm{~mL})$ removed the less polar impurities. Further elution with $\mathrm{CH}_{3} \mathrm{CN}$ $(10 \mathrm{~mL})$ afforded $1.67 \mathrm{mCi}$ of $( \pm) 3-\left[{ }^{125} \mathrm{I}\right]$ iodoMK-801 in $>95 \%$ radiochemical purity as determined by radio-TLC. The radiochemical yield was $23 \%$. HPLC was used for the preparative separation of $( \pm) 3-\left[{ }^{125} I\right]$ iodo-MK-801 from the precursor $( \pm) 3$-bromo-MK-801. The separation was made on an Ultremex IP ${ }^{\mathrm{TM}}$ column with guard column $[0.46 \times(25+5) \mathrm{cm}, 5-\mu \mathrm{m}$ particle, C-18; Phenomenex, Rancho Palos Verdes, Calif.] with a mobile phase consisting of a mixture of $50 \mathrm{mM}$ aqueous ammonium formate $/ \mathrm{CH}_{3} \mathrm{CN}(1: 1)$ and a flow rate of

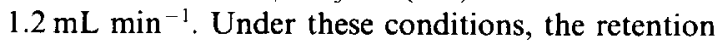
times for 3-hromo-MK-801 and 3-[ ${ }^{125}$ I]iodo-MK-801 were 11.6 and $25.1 \mathrm{~min}$, respectively. During elution of the radioactive peak, 1-min fractions were collected and the heart fractions were pooled.

The effective specific activity and radiochemical purity were assayed by radio-HPLC. The separation was made on an ultrasphere IP ${ }^{\mathrm{TM}}$ column with guard column $[0.46 \times(25+4.5) \mathrm{cm}, 5-\mu \mathrm{m}$ particle sizc, C-18; Beckman Instruments] with $\mathrm{CH}_{3} \mathrm{CN}$ : $0.2 \mathrm{M}$ ammonium formate $(1: 1)$ as eluant and a flow rate of $1.5 \mathrm{~mL} \mathrm{~min}^{-1}$. For this system, the retention times of $\mathrm{MK}-801$, 3-bromo-MK-801, and 3-[ $\left.{ }^{125} \mathrm{I}\right]-$ iodo-MK-801 were $5.0,8.8$, and $10.9 \mathrm{~min}$, respectively. To calculate the effective specific activity, the concentrations of both residual 3-bromo-MK-801 and 3-[ $\left.{ }^{125} \mathrm{I}\right]$ iodo-MK-801 were determined. The concentration of residual 3-bromo-MK-801 was determined by comparing the 3-bromo-MK-801 peak area with that of external standards, while that of $3-\left[{ }^{125}\right.$ I]iodoMK-801 was calculated by assaying the amount of ${ }^{125} \mathrm{I}$ in an aliquot of the preparation in an autogamma counter (Model 1195; TM Analytic, Elk Grove Village, Ill.) and correcting for counting efficiency.

Prior to biological evaluation, the volume of the pooled heart fractions was reduced by evaporation under an argon stream at $40^{\circ} \mathrm{C}$. The remaining aqueous layer was saturated with $\mathrm{NaCl}$, and the radioligand was extracted into hexane. After evaporating the hexane under argon, the radioligand was formulated in ethyl alcohol/phosphate buffered saline, pH 6.5, (15:85).

\section{Preparation of tetrabutylammonium $\left[{ }^{18} \mathrm{~F}\right]$ fluoride}

$\left[{ }^{18} \mathrm{~F}\right]$ Fluoride ion was produced by proton irradiation of $\left[{ }^{18} \mathrm{O}\right]$ water $(86 \%$ isotopic enrichment, 
Mound Laboratories) in an all-silver cyclotron target. Aliquots $(1-50 \mathrm{mCi}, 10-200 \mu \mathrm{L})$ were combined with $2 \mu \mathrm{mol}$ of tetrabutylammonium hydroxide and evaporated in a Vacutainer ${ }^{\mathrm{TM}}$ essentially as per published methods (Brodack et al., 1986). The tetrabutylammonium $\left[{ }^{18} \mathrm{~F}\right]$ fluoride was then resolubilized in $100-200 \mu \mathrm{L}$ of dry acetonitrile and transferred to a suitable reaction vessel. Resolubilization efficiencies were $80-90 \%$.

\section{Synthesis of $( \pm) 13-{ }^{18}$ F]fuoromethyl-MK-801}

To a solution of tetrabutylammonium $\left[{ }^{18} \mathrm{~F}\right]$ fluoride in acetonitrile $(100-200 \mu \mathrm{L})$ was added a solution of $1 \mathrm{mg}$ of either triflamide alcohol 8 or cyclic sulfamate 9 in $50 \mu \mathrm{L}$ acetonitrile, and the solution heated $\left(100^{\circ} \mathrm{C}\right.$, closed vessel) for $5-15 \mathrm{~min}$. The vessel was cooled slightly, then $200 \mu \mathrm{L}$ of $6 \mathrm{~N} \mathrm{HCl}$ added and the aqueous mixture heated $\left(100^{\circ} \mathrm{C}\right.$, closed vessel) for an additional 5-15 min. After brief cooling, the aqueous mixture was added dropwise to $10 \mathrm{~mL}$ of saturated aqueous sodium bicarbonate. This aqueous mixture was then passed through a C-18 Sep-Pak, which was further washed with $5 \mathrm{~mL}$ of water. The product was eluted with $4 \mathrm{~mL}$ of chloroform and the organic solution dried over anhydrous sodium sulfate.

In experiments performed simultaneously, radiochemical yields of ${ }^{18} \mathrm{~F}-\mathbf{3}$ from triflamide alcohol 8 or cyclic sulfamate 9 were essentially identical, 72 and $74 \%$ EOB, respectively. Total synthesis time was $50 \mathrm{~min}$. Radiochemical purity was $>99 \%$ as determined on three TLC systems: silica, $98 / 2$ ethyl acetate $/ \mathrm{NH}_{4} \mathrm{OH} \quad\left(R_{\mathrm{f}}=0.42\right), \mathrm{MK}-801 \quad\left(R_{\mathrm{f}}=0.28\right)$, chloromethyl-MK-801 $\left(R_{\mathrm{f}}=0.51\right)$, hydroxymethylMK-801 $\left(R_{\mathrm{f}} \simeq 0.05\right)$; alumina, $95 / 5$ ethyl ether/ ethanol, $R_{\mathrm{f}}=0.82 ; \mathrm{C}_{18}$ reverse phase, $2 / 1$ ethanol/ water, $R_{\mathrm{f}}=0.25$. Radio-HPLC analysis of the product, with the separation performed on Ultrasphere IP ${ }^{\text {TM }}$ column with guard column $[0.46 \times$ $(25+4.5) \mathrm{cm}$, 5- $\mu \mathrm{m}$ particle size, C-18; Beckman Instruments], $\mathrm{CH}_{3} \mathrm{CN}: 0.2 \mathrm{M}$ ammonium formate

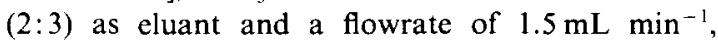
showed a single radioactive peak which co-eluted with authentic 3 . Under these conditions, the retention times of 13-hydroxymethyl-MK-801 (1), MK-801, 13- $\left[{ }^{18}\right.$ F $]$ fluoromethyl-MK-801 (3), and 13-chloromethyl-MK-801 (10) were 6.9, 11.8, 12.9 and $23.4 \mathrm{~min}$, respectively. Analysis of chemical purity by TLC and HPLC showed the presence of traces of the alcohol 1 and chloromethyl-MK-801 (10).

\section{Synthesis of azetidine 5}

Trifluoromethane sulfonic anhydride $(68 \mathrm{mg}$; $0.24 \mathrm{mmol}$ ) was added dropwise to a stirred solution of aminoalcohol 1 (50 $\mathrm{mg} ; 0.20 \mathrm{mmol})$ in anhydrous $\mathrm{CH}_{2} \mathrm{Cl}_{2}$ at $-78^{\circ} \mathrm{C}$ under dry nitrogen. The mixture was stirred at $-78^{\circ} \mathrm{C}$ for an additional $45 \mathrm{~min}$ and then allowed to warm to room temperature over $c a$ $15 \mathrm{~min}$. The reaction was quenched by addition of saturated aqueous $\mathrm{NaHCO}_{3}$ solution $(1 \mathrm{~mL})$; after stirring for $10 \mathrm{~min}$, the aqueous layer was decanted and back-extracted with $\mathrm{CH}_{2} \mathrm{Cl}_{2}(3 \times 3 \mathrm{~mL})$. The combined organic layer and extracts were dricd over $\mathrm{MgSO}_{4}$ and concentrated in vacuo. The crude product was purified by flash chromatography using hexane:ethyl acetate $(2: 1)$ and then $100 \%$ ethyl acetate to give $27 \mathrm{mg}(58 \%)$ of the azetidine 5 as a colorless oil.

${ }^{1} \mathrm{H}-\mathrm{NMR}\left(\mathrm{CDCl}_{3}\right): \delta 2.42(\mathrm{ddd}, 1 \mathrm{H}, \mathrm{J}=9.6,6.3$, $1.5 \mathrm{~Hz}) ; 2.64(\mathrm{~d}, 1 \mathrm{H}, \mathrm{J}=16.6 \mathrm{~Hz}) ; 2.92[\mathrm{dt}, 1 \mathrm{H}$, $\mathbf{J}=7.4(\mathrm{~d}), 9.4(\mathrm{t}), 9.4(\mathrm{t}) \mathrm{Hz}] ; 3.12[\mathrm{dt}, 1 \mathrm{H}, \mathrm{J}=9.2(\mathrm{~d})$, $6.5(\mathrm{t}), 6.5(\mathrm{t}) \mathrm{Hz}] ; 3.39(\mathrm{~d}, 1 \mathrm{H}, \mathrm{J}=5.6 \mathrm{~Hz}) ; 3.40-3.44$ $(\mathrm{m}, 1 \mathrm{H}) ; 4.42(\mathrm{~d}, 1 \mathrm{H}, \mathrm{J}=5.1 \mathrm{~Hz}) ; 6.89-6.92(\mathrm{~m}, 1 \mathrm{H})$; $7.01-7.15(\mathrm{~m}, 3 \mathrm{H}) ; 7.16-7.24(\mathrm{~m}, 3 \mathrm{H}) ; 7.29-7.32$ $(\mathrm{m}, 1 \mathrm{H})$; MS $(70 \mathrm{eV}): m / e 233\left(\mathrm{M}^{+}\right)$; HRMS: $m / e$ calc. for $\mathrm{C}_{17} \mathrm{H}_{15} \mathrm{~N}$ : 233.1204; found: 233.1208 .

\section{Cyclic carbamate 6}

Di-t-butyl dicarbonate $(92 \mathrm{mg} ; 0.42 \mathrm{mmol})$ in DMF $(2 \mathrm{~mL})$ was added to a stirred solution of amino alcohol $1(100 \mathrm{mg} ; 0.40 \mathrm{mmol})$ in DMF $(6 \mathrm{~mL})$ under argon. The reaction mixture was stirred for $2 \mathrm{~h}$ at room temperature and then concentrated under vacuum. The residue was dissolved in $\mathrm{CH}_{2} \mathrm{Cl}_{2}$, washed rapidly with $5 \% \mathrm{HCl}$, and dried over anhydrous $\mathrm{MgSO}_{4}$. The solvent was removed under vacuum to give $90 \mathrm{mg}(64 \%)$ of carbamate as a clear oil. Infrared $(\mathrm{KBr}): v=3440(\mathrm{OH}), 1680(\mathrm{C}=\mathrm{O}) \mathrm{cm}^{-1}$; ${ }^{1} \mathrm{H}-\mathrm{NMR}\left(60 \mathrm{MHz}, \mathrm{CDCl}_{3}\right): \delta 1.35(\mathrm{~s}, 9 \mathrm{H}, \mathrm{t}-\mathrm{Bu})$; $2.40-270(\mathrm{~d}, 1 \mathrm{H}, \mathrm{J}=17.6 \mathrm{~Hz}) ; 2.85-3.30(\mathrm{~m}, 3 \mathrm{H})$; $3.40-4.00(\mathrm{~m}, 3 \mathrm{H}), 5.20-5.40\left[\mathrm{~d}, 1 \mathrm{H}\left(\mathrm{H}_{10}\right), \mathrm{J}=5.7 \mathrm{~Hz}\right)$; $6.80-7.20(\mathrm{~m}, 8 \mathrm{H})$

The above oil was dissolved in $3 \mathrm{~mL}$ of pyridine at $0^{\circ} \mathrm{C}$ and $p$-toluenesulfonyl chloride $(50 \mathrm{mg}$; $0.26 \mathrm{mmol}$ ) was added. The reaction was stirred at $0^{\circ} \mathrm{C}$ for $2 \mathrm{~h}$ and then partitioned between water and $\mathrm{CHCl}_{3}$. The $\mathrm{CHCl}_{3}$ layer was decanted and dried over anhydrous $\mathrm{MgSO}_{4}$. The solvent and residual pyridine were removed under vacuum to give $60 \mathrm{mg}(83 \%)$ of 6 as a white powder, m.p. $258-259^{\circ} \mathrm{C}$. Infrared (neat): $v=1685.2(\mathrm{C}=\mathrm{O}) ;{ }^{1} \mathrm{H}-\mathrm{NMR}\left(\mathrm{CDCl}_{3}\right): \delta 2.49-2.57$ $(\mathrm{m}, 1 \mathrm{H}, \mathrm{J}=14.5 \mathrm{~Hz}) ; 2.77-2.81(\mathrm{~d}, 1 \mathrm{H}, \mathrm{J}=16.9 \mathrm{~Hz})$; $3.15-3.20(\mathrm{~m}, \quad 1 \mathrm{H}, \quad \mathbf{J}=14.5 \mathrm{~Hz}) ; 3.62-3.68 \quad(\mathrm{dd}$, $1 \mathrm{H}, \mathrm{J}=16.9 \mathrm{~Hz}) ; 4.24-4.31(\mathrm{~m}, 1 \mathrm{H}, \mathrm{J}=11.2 \mathrm{~Hz})$; $4.35-4.40(\mathrm{~m}, 1 \mathrm{H}, \mathrm{J}=11.2 \mathrm{~Hz}) ; 5.70-5.72(\mathrm{~d}, 1 \mathrm{H}$, $\mathbf{J}=5.5 \mathrm{~Hz}) ; 7.00-7.06(\mathrm{~m}, 2 \mathrm{H}) ; 7.13-7.21(\mathrm{~m}, 5 \mathrm{H})$; $7.34-7.36(\mathrm{~m}, 1 \mathrm{H})$; MS $(70 \mathrm{eV}): m / e 277\left(\mathrm{M}^{+}\right)$; HRMS: $m / e$ calc. for $\mathrm{C}_{18} \mathrm{H}_{15} \mathrm{NO}_{2}: 277.323$. Found: 277.1103. Anal. calc. for $\mathrm{C}_{18} \mathrm{H}_{15} \mathrm{NO}_{2} \cdot \frac{1}{2} \mathrm{H}_{2} \mathrm{O}: \mathrm{C}, 75.50$; H, 5.63; N, 4.89. Found: C, 75.60; H, 5.67; N, 4.79.

\section{Results and Discussion}

\section{Chemistry}

The direct iodination of $( \pm) \mathrm{MK}-801$ by the Derbyshire method (Derbyshire and Waters, 1950) provided an unexpectedly simple monoiodinated product pattern. It was anticipated that under conditions of stoichiometric excess of $( \pm) \mathrm{MK}-801$ at least four compounds, the 2-, 3-, 7- and the 8-monoiodo 
isomers might be formed. A major monoiodinated isomer was isolated from this reaction. The ${ }^{1} \mathrm{H}$ and ${ }^{13} \mathrm{C}$ NMR data, however, strongly support 1 -iodo$\mathrm{MK}-801$ as the structure of this compound. The aromatic region of the ${ }^{1} \mathrm{H}$ NMR spectrum clearly shows a coupling pattern suggesting substitution of one of the four protons ortho to the seven-membered ring (i.e. $\mathrm{C}_{1} \mathrm{H}, \mathrm{C}_{4}-\mathrm{H}, \mathrm{C}_{6}-\mathrm{H}$ or $\mathrm{C}_{9}-\mathrm{H}$ ). In addition, there is a small upfield shift in the signals of the two $\mathrm{C}_{11}$-protons relative to parent $\mathrm{MK}-801$, which can be attributed to a shielding effect by the iodine atom in the $C_{1}$ position. The last observation is reinforced by the significant downfield shift ( $c$ a $7.3 \mathrm{ppm}$ ), relative to MK-801, observed for $\mathrm{C}_{11}$ in the ${ }^{13} \mathrm{C}$ NMR spectrum of the iodo compound. This shift can be best attributed to the presence of the iodine atom in the adjacent $C_{1}$ position. Finally, direct comparison of the ${ }^{1} \mathrm{H}$ and ${ }^{13} \mathrm{C}$ NMR spectra of the monoiodo compound with those of 3-bromo-MK-801 also points to the 1-iodo-MK-801 isomer as the structure of the product. Whether this remarkable preference for electrophilic attack at the 1-position of MK-801 is unique to the Derbyshire reaction remains to be determined. The identity of the two minor monoiodinated products has not been pursued.

The radiosynthesis of $( \pm) 1-\left[{ }^{125}\right.$ I]iodo-MK-801 was readily achieved by the solid-state radioiodide exchange method previously developed in this laboratory (Mangner et al., 1983; Otto et al., 1986). Rapid passage of the reaction mixture through a silica Sep-Pak ${ }^{\mathrm{TM}}$ to eliminate unreacted radioiodide and other radioactive inorganics was the only purification necessary. A radiochemical yield of $83 \%$ was obtaincd ata specific activity of $60 \mathrm{Ci} / \mathrm{mmol}$; higher specific activities $(>100 \mathrm{Ci} / \mathrm{mmol})$ could be achieved but in lower yield.

The synthesis of $( \pm) 3-\left[{ }^{125} \mathrm{I}\right]$ iodo-MK-801 was accomplished by interhalogen exchange with ( \pm )3-bromo-MK-801. Subsequent use of HPLC was needed to separate most of the $( \pm)$ 3-bromo-MK-801 precursor from the desired radioactive product. This HPLC enrichment gave $( \pm) 3-\left[{ }^{125} \mathrm{I}\right]$ iodo-MK-801 with an effective specific activity of $>1350 \mathrm{Ci} / \mathrm{mmol}$. The synthesis of unlabeled 3-iodo-MK-801 has not been reported and its synthesis is presently being pursued in our laboratory. Thus, the evidence for the identity of $( \pm) 3-\left[{ }^{125} I\right]$ iodo-MK-801 is indirect. The fact that only one radioactive organic product is formed and that its chromatographic behavior, both TLC and HPLC, is very similar to 3-bromo-MK-801, argues strongly for interhalogen exchange rather than proton-halogen exchange. Further support for interhalogen exchange rests on findings in our laboratory that ortho-chlorobenzylguanidine and PK-11195, an ortho-chlorophenyl derivative of isoquinoline, undergo exclusive interhalogen exchange with $\mathrm{Na}^{125} \mathrm{I}$ under the solid-state conditions employed here for ( \pm )3-bromo-MK-801 (Gildersleeve et al., 1988).

The most obvious strategy for labeling MK-801 with a positron-emitting radioisotope is to synthesize
Table 1. Structure of MK-801 derivatives

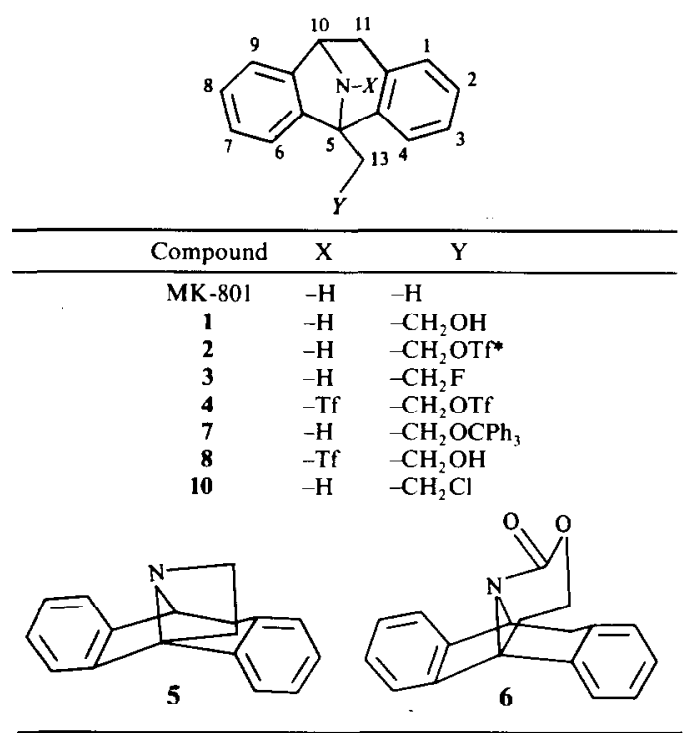

$* \mathrm{Tf}=\mathrm{SO}_{2} \mathrm{CF}_{3}$

$\mathrm{N}-\left[{ }^{11} \mathrm{C}\right]$ methyl-MK-801 with a ${ }^{11} \mathrm{C}$-labeled methylating agent (i.e. $\left[{ }^{11} \mathrm{C}\right]$ methyl iodide). This in fact has been done in our laboratory (Watkins G. L. and Jewett D. M., unpublished). However, as shown in Table 2, N-methyl-MK-801 has a 2-fold lower binding affinity than MK-801 in the $\left[{ }^{3} \mathrm{H}\right] \mathrm{TCP}$ assay. Thus, alternatives to labeling MK-801 with carbon11 have been pursued, especially those employing $\left[{ }^{18} \mathrm{~F}\right]$ fluoride ion because of its longer half-life, ease of large-batch synthesis, and high specific activity. Our attention focused on the bridgehead methyl group as a possible locus for incorporating ${ }^{18} \mathrm{~F}$. This approach was attractive since the synthesis of the methylenehydroxy derivative of MK-801, i.e. compound 1 , has been described in the patent literature (Christy et al., 1979). It was predicted that the triflate of this alcohol, 2, could serve as a precursor to ${ }^{18} \mathrm{~F}-\mathbf{3}$, the 13- $\left[{ }^{18} \mathrm{~F}\right]$ fluoromethyl derivative of MK-801.

Alcohol 1 was synthesized in 7 steps from trans -10 , 11-dibromodibenzosuberone. Reaction of 1 with 1.2 equivalents of triflic anhydride failed to give the desired triflate 2 ; instead the azetidine derivative 5 was formed, seemingly through nitrogen attack on the triflate formed in situ. The azetidine was also observed in the reaction of 1 with DAST (Mislankar and Wieland, unpublished observation). Reaction of 1 with 2.5 equivalents of triflic anhydride gave the triflate sulfonamide 4 . The imino group of 1 could be selectively functionalized as the t-BOC carbamate; however, subsequent attempts to form the triflate in the presence of organic bases resulted in intramolecular cyclization to the carbamate 6 . Reaction of 1 with trityl chloride gave the $\mathrm{O}$-alkylated product 7 ; reaction of 7 with triflic anhydride followed by an aqueous acid workup yielded the triflamide 8 . At this stage in our synthetic work, Merck scientists reported 


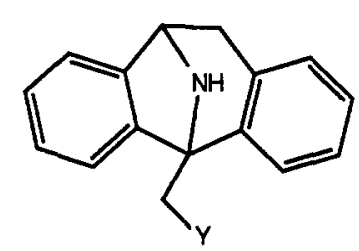

$1 \quad \mathrm{Y}=\mathrm{CH}_{2} \mathrm{OH}$

Z $\mathrm{Y}=\mathrm{CH}_{2} \mathrm{OCPh}_{3}$
$\left(\mathrm{CF}_{3} \mathrm{SO}_{2}\right)_{2} \mathrm{O}$<smiles>COc1ccccc1N1C2c3ccccc3C1(CCO)c1ccccc12</smiles>

8

$\mathrm{NaH}$

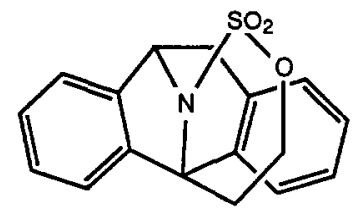

2

3

Fig. 1. Synthesis of $( \pm) 13-\left[{ }^{18}\right.$ F]fluoromethyl-MK-80I.

a similar synthesis of triflamide 8 and detailed its anomalous reaction with $\mathrm{Bu}_{4} \mathrm{~N}^{+} \mathrm{F}^{-}$to give 3 (Lyle et al., 1987). The Merck scientists have demonstrated that this unusual fluorination reaction proceeds through the in situ formation of the cyclic sulfamate 9 as shown in Fig. 1. Our results reported here, in which either the sulfonamide alcohol 8 or the cyclic sulfamate 9 give high and nearly identical radiochemical yields of ${ }^{18} \mathrm{~F}-3$ upon reaction with $\mathrm{Bu}_{4} \mathrm{~N}^{+18} \mathrm{~F}^{-} / \mathrm{Bu}_{4} \mathrm{~N}^{+} \mathrm{OH}^{-}$, supports this view. The identity of ${ }^{18} \mathrm{~F}-3$ was confirmed by TLC and HPLC comparison with authentic 3 , synthesized by the Merck method. This anomalous radiochemical reaction is also remarkable in that it gives exceedingly high ${ }^{18} \mathrm{~F}$ incorporation and a product of high radiochemical purity $(>99 \%)$. Isolated yields are as high as $68 \%(93 \%$ corrected for decay); virtually the only other fluorine-18 species is unreacted $\left[{ }^{18} \mathrm{~F}\right]$ fluoride ion which can be removed by a variety of methods, including liquid-liquid extraction or bonded-phase chromatography. Chemical impurities are few, but are apparently different depending on the choice of starting material. Trace chemical impurities such as 1 are removed from the final product by HPLC purification. With further optimization studies, it will likely be possible to eliminate the tracer chemical impurities by a simple Sep-Pak procedure. When aqueous $\mathrm{HCl}$ is used in the radiochemical workup of the $\left[{ }^{18} \mathrm{~F}\right]$ fluoride reaction with the cyclic sulfamate 9 , the chloromethyl analog 10 has been observed to form, seemingly through $\mathrm{Cl}^{-}$attack on the cyclic sulfamate 9 . Use of the hydroxytriflamide 8 gives no chloromethyl contaminant on aqueous $\mathrm{HCl}$ workup. Compound 10 was synthesized separately by reaction of 1 with thionyl chloride.
Table 2. MK-801 derivatives: binding affinities

\begin{tabular}{lc}
\hline Compound & $K_{\mathrm{i}} \pm \mathrm{SD}(\mathrm{nM})^{*}$ \\
\hline$(+) \mathrm{MK}-801$ & $22 \pm 2$ \\
$( \pm)$ MK-801 & $79 \pm 11$ \\
$( \pm)$ N-Methyl-MK-801 & $158 \pm 22$ \\
$( \pm)$-Iodo-MK-801 & $790 \pm 110$ \\
$( \pm) 3$ - Bromo-MK-801 & $0.8 \pm 0.3$ \\
$( \pm)$ 3-Fluoromethyl-MK-801 & $79 \pm 22$ \\
\hline$N=3$. &
\end{tabular}

\section{Binding and $\log P$ studies}

Substitution of iodine in the 1-position decreases the binding affinity 10-fold (Table 2). Although unlabeled ( \pm )3-iodo-MK-801 was not available for competitive binding studies, it is noteworthy that ( \pm )3-bromo-MK-801, which is likely to mimic the 3-iodo isomer, has a 100-fold greater affinity than $( \pm) M K-801$ and a 1000 -fold greater affinity than $( \pm) 1$-iodo-MK-801 for the TCP binding site. This high sensitivity to the halogen substitution pattern underscores the need to do further SAR studies.

Results of binding studies with $( \pm) \mathrm{N}$-methyl-MK801 and $( \pm) 13$-fluoromethyl-MK-801, derivatives amenable to labeling with ${ }^{11} \mathrm{C}$ and ${ }^{18} \mathrm{~F}$, respectively, show that $\mathrm{N}$-methylation slightly lowers binding affinity, whereas fluoromethylation of the bridgehead methyl group has no observable effect on binding. The radiotracers synthesized in this study are racemic ligands; however the $(+)$ enantiomers are expected to show enhanced binding (See Table 2).

It has become clear in recent years that a "window" of lipophilicity exists for optimum passage of a drug or tracer through the blood-brain barrier (Hansch et al., 1987). This optimum $\log P$ is $2 \pm 0.5$. A $\log P$ value of $2.1 \pm 0.1$ was obtained for free base 
MK-801. The addition of an iodine atom to MK-801 will likely raise the $\log P$ to approximately 3 ; incorporation of the fluoromethyl group should have a lesser effect (Leo et al., 1971). In any case, CNS penetration should not be an obstacle for the tracer MK-801 derivatives synthesized in this study.

\section{Conclusions}

MK-801, a drug that binds with high affinity and selectivity to the glutamate-linked cation channel in mammalian brain, can be radiolabeled as a tracer for possible use in both SPECT and PET imaging techniques. This preliminary work lays the groundwork for a more detailed study of radiolabeled MK-801 derivatives as possible NMDA receptor-based imaging agents. It clearly demonstates that foreign isotopes, both large $\left({ }^{125} \mathrm{I}\right)$ and small $\left({ }^{18} \mathrm{~F}\right)$, can be incorporated into the MK-801 framcwork by convenient, high-yield methods without compromising the binding affinity. A number of reactions involving the MK-801 ring structure are unusual. One of these, the in situ formation of a cyclic sulfamate, provides an unexpectedly easy method for fluorine-18 labeling MK-801. In vivo evaluation of $( \pm) 3-\left[{ }^{125}\right.$ I]iodoMK-801 and $( \pm) 13-\left[{ }^{18}\right.$ F]fluoromethyl-MK-801 is in progress.

Acknowledgements - We gratefully acknowledge support of this research by the National Institute of Health (Grants NS25656 and NS15655). We thank Linder Markham for preparing the manuscript and Dr William Kerr for the use of the radiochemical laboratories at the Phoenix Memorial Laboratory, University of Michigan. We are also indebted to Dr Edward F. Domino for the use of his GC/MS unit.

\section{References}

Albin R. L., Young A. B. and Penney J. B. (1988) Tetrahydro-9-aminoacridine (THA) interacts with the phencyclidine (PCP) receptor site. Neurosci. Lett. (In press).

Anderson P., Christy M. E. and Evans B. E. (1983) 5-Alkyl or hydroxyalkyl substituted-10,11-dihydro-5Hdibenzo[a/d]cyclophepten-5,10-imines and anticonvulsant use thereof. US Patent 4, 399, 141.

Bender D. R., Karady S. and Rothauser T. (1984) 5-Methyl-10,11-dihydro-5H-dibenzo[A,D]cyclohepten5,10-imine. US Patent 4, 477,668.

Bradford M. M. (1976) A rapid and sensitive method for the microgram quantitation of protein utilizing the principle of protein-dye binding. Anal. Biochem. 72, 248.

Brodack J. W., Kilbourn M. R., Welch M. J. and Katzenellenbogen J. A. (1986) 16-[F-18]Fluoroestradiol: The effect of reaction vessel on fluorine-18 resolubilization, product yield, and effective specific activity. Appl. Radiat. Isot. 37, 217.

Christy M. E., Anderson P. S., Britcher S. F., Colton C. D., Evans B. E., Remy D. C. and Engelhardt E. L. (1979) Transannular reactions of dibenzo[a,d]cycloalkenes. 1 . Synthesis of dibenzo[a,d]cycloocten-6,12-imines and dibenzo[a,d]cyclo-hepten-5,10-imines. J. Org. Chem. 44, 3117.

Derbyshire D. H. and Waters W. A. (1950) A method of direct iodination of aromatic compounds. J. Chem. Soc. 3694.

Deutsch S. I. and Morihisa J. M. (1988) Glutamatergic abnormalities in Alzheimer's Disease and a rationale for clinical trials with L-glutamate. Clin. Neuropharm. 11, 18.

Frey K. A., Wieland D. M., Brown L. E., Rogers W. L. and Agranoff B. W. (1981) Development of a tomographic myelin stain. Ann. Neurol. 10, 214.

Gildersleeve D. L., Lin T-Y., Wieland D. M., Ciliax B. J. and Young A. B. (1988) Synthesis of high specific activity [25 I]PK11195, a potential agent for SPECT imaging of the peripheral benzodiazepine receptor. Nucl. Med. Biol. (In press) (MS 169).

Greenamyre J. T., Penney J. B., Young A. B., D'Amato C. J., Hicks S. P. and Shoulson I. (1985) Alternations in L-glutamate binding in Alzheimer's and Huntington's Disease. Science 227, 1496.

Hansch C., Bjorkroth J. P. and Leo A. (1987) Hydrophobicity and central nervous system agents: On the principle of minimal hydrophobicity in drug design. J. Pharm. Sci. 76, 663.

Honey C. R., Miljkovic Z. and MacDonald J. F. (1985) Ketamine and phencyclidine cause a voltage-dependent block of responses of L-aspartic acid. Neurosci. Lett. 61, 135.

Kemp J. A., Foster A. C., Gill R. and Woodruff G. N. (1987) MK-801, NMDA receptors and ischaemia-induced neurodegeneration. TIPS 8, 414.

Leo A., Hansch C. and Elkins D. (1971). Partition coefficients and their uses. Chem. Rev. 71, 525.

Lyle R. A., Magill C. A. and Pitzenberger S. M. (1987) Fluoride-induced formation and ring opening of cyclic sulfamates from hydroxytriflamides. Synthetic and mechanistic studies. J. Am. Chem. Soc. 109, 7890.

Mangner T. J., Wu J-L. and Wieland D. M. (1982) Solid-phase exchange radioiodination of aryl iodides. Facilitation by ammonium sulfate. J. Org. Chem. 47, 1383.

Meldrum B. Excitatory amino acids and epilepsy. In Excitatory Amino Acid Transmission (Eds Hicks T. P. Lodge D. and McLennan H.) pp. 189 -196. Alan R. Liss, New York, 1987

Olney J. W. (1987) Excitatory amino acids and neuropsychiatric disorders. In Excitatory Amino Acid Transmission (Eds Hicks T., Lodge D. and McLennan H.), pp. 217-224. Alan R. Liss, New York.

Otto C. A., Lee H., Mangner T. J. and Wieland D. M. (1986) $\omega$-Iodophenyl fatty acids: A convenient method of radioiodination. Appl. Radiat. Isot. 37, 205.

Still W. C., Kahn M. and Mitra A. (1978) Rapid chromatographic technique for preparative separations with moderate resolution. J. Org. Chem. 43, 2923.

Vignon J., Chicheportiche R., Chicheportiche M., Kamenka J-M., Geneste P. and Lazdunski M. (1983) [ $\left.{ }^{3} \mathrm{H}\right] \mathrm{TCP}$ : A new tool with high affinity for the PCP receptor in rat brain. Brain Res. 280, 194-197.

Vignon J., Privat A., Chaudieu I., Thierry A., Kamenka J-M. and Chicheportiche R. (1986) [ $\left.{ }^{3} \mathrm{H}\right] \mathrm{TCP}$ binds to two different sites in rat brain localization by autoradiographic and biochemical techniques. Brain Res. 378, 133-141.

Watkins J. C. and Evans R. H. (1987) Excitatory amino acid transmitters. Ann. Rev. Pharmacol. Toxicol. 21, 165

Wong E. H. F., Knight A. R. and Woodruff G. N. (1988) $\left[{ }^{3} \mathrm{H}\right] \mathrm{MK}-801$ labels a site on the $\mathrm{N}$-methyl-D-aspartate receptor channel complex in rat brain membranes. J. Neurochem. 50, 274.

Wong E. H. F., Kemp J. A., Priestly T., Knight A. R., Woodruff G. N. and Iversen L. L. (1986) The anticonvulsant $\mathrm{MK}-80 \mathrm{l}$ is a potent $\mathrm{N}$-methyl-D-aspartate antagonist. Proc. Natl. Acad. Sci. U.S.A. 83, 7104. 